\title{
The Audit of State Finances in Realize Good Governance: Parliament Perspective
}

\author{
Dani R. Pinasang, Achmad Ruslan, Abdul Razak, A. Pangerang Moenta \\ Graduate School, Hasanuddin University, South Sulawesi, Indonesia
}

\begin{abstract}
The management and responsibilities of state finance occupies important position of the state and nation. The amount of irregularities in the State financial is also evidenced by the results of auditing the State finances by the State Audit Board. The type of this research is a normative-empirical because this study is focused on the instrument of legislation related to State finances. The research is located in Jakarta, in the Office of the House of Representatives of the Republic of Indonesia, the Office of the Ministry of State Finance, and the Office of the Finance Audit Board of the Republic of Indonesia. The results shows that the essence of supervisory function of the Indonesian House of Representatives, philosophically based on manifestation of the principle of rule of law as well as sovereignty of the people principles as stipulated in the 1945 Constitution. The supervisory function of Parliament to executive including the management and responsibility of the State finances.
\end{abstract}

Keywords: - Checks and Balances, Good Governance; Parliament, State Finances

\section{INTRODUCTION}

The constitutional reform in Indonesia cannot be separated from a series of important events in the era of 1999-2002, such as the amendment of the 1945 constitutional. This amendment cannot be separated from Indonesia's administrative structure which was originally drafted by executive heavy and lack the principle of checks and balances. ${ }^{1}$ It clearly in the New Order era in which the legislature are only as an institution that provides a "stamp" to all the government's wishes. Amendment of the 1945 constitution that gives strong powers to the Parliament as well as strengthen the construction of the checks and balances between state institutions. Strengthening the Parliament in line with format strengthening our institutional that puts Indonesia as presidential country. ${ }^{2}$

Strengthening the parliament is reflected in the strengthening of three main functions, namely legislation, control and budget. The authority to form the law is no longer in the hands of the president, but has switched to the Parliament. Draft bill which has been approved with the President and the House of Representatives and then did not get the legalization of the President, still automatically become law. ${ }^{3}$ Besides a more powerful authority in the legislation, another strong authority is in terms of control or supervision. The control of Parliament to the government and other institutions is so large. The essence of control is supervision to the implementation of laws and budget.

Hence, to implement the duties and its activities in the context of control, the Parliament is given a series of rights as follows: The right of interpellation and asking, the right of investigation into cases of alleged violations by the Government, the right of resolution or a statement of opinion and the right to call or memorandum to exercise its authority, the Parliament was given the right of institutional and individual of members of Parliament. ${ }^{4}$ That is, independently of each member of the MPR, DPR and DPD in exercise their constitutional duties as elected representatives or as members of parliament are the official duties of office, and they were given certain rights inherent in their position, the rights of position is related to the implementation of duties as Parliament's member.

In this regard, the management and responsibilities of state finance occupies important position in the life of State and nation, it is closely related to the process of achieving State's objectives. Accelerating the achievement of objectives are very noble as mentioned above is very dependent on State government that exercising government functions in a variety of areas, where the activities of government in realizing the objectives of the State as mentioned above certainly give rise to rights and obligations of the State, which can be

\footnotetext{
1 Saldi Isra, Pergeseran Fungsi Legislasi, Jakarta: PT Raja Grafindo Persada, 2010, p. 156.

2 Deny Indrayana, Amandemen UUD 1945: Antara Mitos dan Pembongkaran, Bandung: Mizan, 2007, p. 276.

3 Moh. Mahfud, Perdebatan Hukum Tata Negara Pasca Amandemen Konstitusi, Jakarta: LP3ES, 2007, p. 66 168.

4 Jimly Asshiddiqie. Format Kelembagaan Negara Dan Pergeseran Kekuasaan Dalam UUD 1945, Yogyakarta: FH UII Pers, 2002, p. 
valued in money and should be managed in a systems of management and responsibility of the State finance, with refers and based on the provisions of the legislation in force, as well as on the principles and the basic principles of management and responsibilities of State finance in Indonesia and internationally.Good realization of management and responsibilities of State finance as a factor or element that determines the system in terms of control or supervision. The number of agencies/institutions, and civil society to control State finance exist, they should give a good contribution in reducing violations and fraud that occurred in the management and responsibilities of the State finance, but in fact it is very ironic as a number of violations occur, abuses and corruption in Indonesia. In auditing the management and responsibility of the State finance requires a standard. Poor management and responsibility of the State finance result in corruption, collusion and nepotism. It indicates the implementation of our government system is not rests entirely on the general principles of good governance, especially in the implementation of State finance has not optimal. Political and Economy Risk Consultancy, a consulting firm based in Hongkong, according to a report of 2014, that Indonesia as a most corrupt country in the Asia-Pacific. Likewise, the report of Transparency International in latest survey, that Indonesia was still in 143 of 179 countries in the world in efforts to combat corruption. With the rating, Indonesia in 36 as the weakest country in the world to eradicates corruption. In January 2016, Transparency International confirm that despite efforts to eradicate corruption began improved but compared to other countries of Asia-Pacific, Indonesia is still considered as a most corrupt country. ${ }^{5}$

The amount of irregularities in the State financial is also evidenced by the results of auditing the State finances by the State Audit Board. A total of 4.900 cases in worth Rp. 25.74 trillion is finding impacted financially as findings of non-compliance with the provisions of the legislation that resulted in losses, losses potential, and lack of revenue. While, the monitoring of follow-up as result recommendation of auditing, revealed that in the period of 2010 until 2014 (First Semester), BPK convey recommendations to the result of audit for entity as much as Rp. 201.976 recommendations in worth Rp. 66.17 trillion. From 102.719 recommendations in worth Rp. 22.45 trillion that followed-up according to recommendations of which have been followed-up by payment/asset delivery to State/regions/companies cumulatively since 2010 until 2014 (First semester) in worth Rp. 12.69 trillion. $^{6}$

Based on data presented above can be seen the irregularities of State financial is so great in number that is very detrimental to the State finances. This condition is very ironic with still many Indonesian people as sovereign holder is very poor. And more ironic is irregularities in the management and responsibility of the State finance occurs in the midst of many institutions and agencies/bodies of State financial control in Indonesia, in surveillance system which still seems to be confusion. Such bad circumstances, requires optimization of good performance for all parties, in particular the specialized institutions to control the State financial to heal the deteriorating circumstance (therapeutic bad circumstances).

DPR as finished maker has a foundation in philosophical, theoretical and constitutional jurisdiction. Philosophically, the fourth principle of Pancasila "The democracy led by understanding among honorable representatives from the parliament house," is a way of life, weltanschaung, philosophy of life, a matter of life or advice of life, ${ }^{7}$ this is one of the philosophical foundation of representative body in Indonesia, as well as the implementation of the sovereignty of the people, and implemented in the 1945 Constitution. Likewise, DPR as finished maker could be studied theoretically and constitutional jurisdiction.

Not complete the legal proceedings against the irregularities of State finance, beside the responsibility of law enforcer institution: police, attorney and also become the Parliament's responsibility which has control functions, including management and responsibility of the State finance. Control by the House of Representatives or Parliament of the management and responsibility of the State finance must have legal certainty, the legal certainty from the aspect of governance, and from the aspect of legal liability.

\section{METHOD OF THE RESEARCH}

This research is normative-empirical because this study is focused on the instrument of legislation related to State finances. The research is located in Jakarta, in the Office of the House of Representatives of the Republic of Indonesia, the Office of the Ministry of State Finance, and the Office of the Finance Audit Board of the Republic of Indonesia. This research uses statute approach related to the legislation and regulation. In addition, it is also supported by the political approach and case approach. ${ }^{8}$ The method of analysis used is a qualitative and quantitative, with this method conduct analysis or content of analysis to the implementation of the State finance control.

\footnotetext{
${ }^{5}$ TI Report on http://www.ti.or.id/index.php/publication/2016/01/27/corruption-perceptions-index-2015, Accessed on 27 January 2016 ${ }^{6}$ Ibid

7 Fitria. Penguatan fungsi DPR Melalui Perubahan Undang-undang No. 10 Tahnu 1954 tentang Hak Angket. Jurnal Cita Hukum, Vol. 1. No. 1. June 2014.

${ }^{8}$ Peter Mahmud Marzuki., 2010. Penelitian Hukum. Jakarta: Kencana, p. 21

DOI: 10.9790/0837-2204051016 www.iosrjournals.org $11 \mid$ Page
}




\section{AN OVERVIEW OF AUDITING BY BPK AND NOTES OF THE STATE FINANCIAL LOSSES IN 2014-2016}

The Finance Audit Board of the Republik Indonesia (Badan Pemeriksaan Keuangan-BPK) is the agency mandated by the 1945 Constitution to audit the management and responsibility of the State finance (Article 23E paragraph (1) the 1945 Constitution). BPK is a one party that plays a major role in maintaining and ensuring the State finance is utilized to the welfare of the people. The whole development activities in any field are always using State money, whether economic, political, social, and culture. Utilization the State money does not obey the rules can result in not achieving its intended purpose. Therefore, through the audit, BPK may encourage the utilization of State finances in a transparent and accountable for the welfare of the people.

In recent years, BPK prioritized the audit as mandatory or should be done as a command of constitutional. It also prioritizes audit on the fields of activity are prone to corruption and being of the priority of development such as education, health, infrastructure, environment, food security, and overcoming of poverty. The constrain faced by BPK in audit is the high expectation from the people who want if an entity obtaining WTP opinion then it should be no corruption in the entity. By the expectations of people, BPK continued to improve audit quality by increasing the understanding of Risk-Based Audit (RBA) and develop audit based on information technology so that the audit can be performed with a scope broader audit and not limited to the number of samples is limited.

In the first semester of 2014, BPK RI found the problem of oil and gas tax revenues in worth Rp. 1.12 trillion consisting of the potential of debt Land and Building Tax for oil and gas a minimum of Rp. 666.23 billion and the potential of tax revenue shortfall a minimum of Rp. 454.38. BPK also found non-compliance the Cooperation Contrast Contractor about the provision of cost recovery, resulting in state revenue shortfall in worth Rp. 6.19 trillion. Also, BPK revealed another problem faced by the central government is about infrastructure spending in the Ministry of Energy and Mineral Resources. BPK discovered 137 transmission construction project contracts and main station stopped. With the cessation of the project causing unfinished projects in worth Rp. 5.38 trillion cannot be utilized. In addition, there are State losses in worth Rp. 562.66 billion over the rest of the advances that are not returned by the provider of goods/services. ${ }^{9}$

In 2015, the auditing of BPK in the overview of Audit Result in Semester I, BPK find as many as 10.154 findings containing 15.434 problems, which include $7.890(51.12 \%)$ as non-compliance to the legislation in worth Rp. 33.46 trillion and $7.544(48.88 \%)$ as weaknesses of internal control system. The problem of non-compliance, a total of 4.609 have an impact on the financial recovery of the State/ region/entity (or financial impact) in worth Rp. 21.62 trillion.

IHPS's notes about State Losses in 2016, BPK's audit in semester I is largely or almost entirely the result of an audit. The problem of financial impact consisting of 66 percent as problem resulting in State losses in worth Rp. 1.92 trillion, 9 percent as problem resulting in potential losses to the State in worth Rp.1.67 trillion, and 25 percent as problem resulting in shortages of revenue in worth Rp. 27.03 trillion. For the problem of non-compliance that impacted financially, during the auditing process, the entity has followed up by handing over assets to the state treasury in worth Rp. 442.4 billion.

In addition, since 2010 to Semester I 2016, BPK has delivered 283.294 recommendations in worth Rp.247.87 to the audited entity. For this, as many as $61 \%$ of recommendations have been followed up according to the recommendations. Cumulatively to Semester I 2016, BPK's recommendations that were successfully followed-up by delivery of assets and money to the State treasury, local or enterprise to the audit in worth Rp. 37.60 trillion. $^{10}$

\section{IMPLEMENTATION OF PARLIAMENT'S CONTROL FUNCTIONS}

The Parliament conducts control for various policies issued by the government that have an impact on the lives of the people as a whole. Implementation of the control function by parliament through various forms such as meetings (working meetings and public hearing), a working visit (specific working visit and recess), establishment of team and Working Committee, giving consideration and approval of the proposed appointment of public officials. In addition, the implementation is also done through the use of Parliament's rights ${ }^{11}$ such as the right of interpellation (request for information), the right of inquiry and the right to express opinions.

The Parliament is often criticized related to not maximal control function. For example, Forum Masyarakat Peduli Parlemen Indonesia (Formappi) appraise the House of Representatives (DPR) has not run a good control. DPR do not show the firmness in the field of control, especially during the second session in 2015. Follow-up of the House of Representatives in the field of control is still weak. Do not show any results. There are at least

\footnotetext{
${ }^{9}$ BPK Report: http://www.bpk.go.id/assets/files/ihps/2014/II/ihps ii 2014 1428982182.pdf downloaded on Wednesday 1 February 2016 at 15.30 .

${ }^{10}$ BPK RI. http://www.bpk.go.id/assets/files/ihps/2016/I/ihps_i_2016_1475566035.pdf downloaded on Wednesday 1 February 2016 at 15.30 .

${ }_{11}$ Asmara, G. (2015). Penguatan Kelembagaan MPR dalam Sistem Ketatanegaran Negara Republik Indonesia. Hasanuddin Law Review, 1(3), 357-370. doi: http://dx.doi.org/10.20956/halrev.v1n3.115 
three responsibilities of the Parliament in control. First, the House of Representatives should follow up on the findings of the Finance Audit Board over 4.900 suspected cases resulting in losses to the State that do government agencies. Of these, only 17 cases were taken up by the House of Representatives in 2015 ago. The follow up was considered not serious. Beyond receiving the report, the Parliament should pass on the evidence of the violation found to law enforcement agencies.Throughout 2016 the control function of House of Representatives was still not optimal. Indeed, Parliament has conducted control to the aspects of their duties. Even so, the control conducted is seemed barren and unable to fix the weaknesses observed. One is related to follow-up the findings of the Finance Audit Board. It impacts on the State financial losses and the lack of sufficient state revenues. On other hand, deposits to the State treasury by ministries/agencies on State losses and the lack of State revenue is still very small. ${ }^{12}$ Two criticisms that are often addressed to the House of Representatives are related to the function of legislation and control. Related to control function, many parties criticize, if the control function of House of Representatives is still tends to be partial and selective for their own interests such as in the context of law enforcement. Parliament is often highlighted the tapping function by Eradication Corruption Commission. But never questioned tapping against other law enforcement officers.

Challenges of the House of Representatives in exercise control function are to balance supervisory activities itself with strong demands from the public to various functions attached to the House of Representatives. In a legislative function, especially in terms of quality and quantity of products produced legislation, Parliament should be aware that the challenge to produce more quality legislation must be accompanied by supervision over the implementation of legislation product itself. The increasing of complaints/aspiration that goes to the House of Representatives a challenge for Parliament. The use of technology has become a global demand of the parliament in the world to build a better interpersonal communication and democratic society.Control function should be the barometer which ensures that every performance made the Parliament is not only to meet the target, but truly accountable to the peoples' interests. In this position, optimization of control function is strategically placed. However, it should be recalled also that the supervisory or control function should always be followed up with concrete actions of the Parliament on an issue or problems encountered in the implementation of legislation in the field. A clear time frame on treatment or follow-up of the supervisory activities of the Board should be clearly defined. This should be a concern of the Board that any findings obtained in the control activities can be handled thoroughly, not just a collection of data are not optimally followed.

House of Representatives also must always hold to the schedule of activities that actually drafted carefully in each year session based on priorities that is really feels crucial implications for the issues or problems associated with the interests or welfare of the community. One more thing that should not be overlooked by the House of Representatives is that the Parliament needs to encourage the Government to continue to follow up with quick recommendations that delivered the House of Representatives on issues or problems are found the Parliament in control. This is very important because if the government did not follow up optimally, then delivering solutions for social problems, problems of the nation, and the country's problems can be obstructed and disturbed. This is where the challenge to be faced by the House of Representatives, where the House of Representatives should do everything possible to create synergies implementing the control functions in conjunction with the Government. Giving understanding and encouragement to the Government is crucial in this context.

Efforts improvements that need to be encouraged is the formation of the Parliament's Supervisory Guidelines which currently has draft so it might be adapted to the provisions of the new legislation. Besides, Rules of Conduct mandates that every apparatus of Parliament should establish working procedures as more detailed guidelines on the implementation of the control function to be set into the rules of Parliament. By upgrading the status of the existing rules into the rules of Parliament, the expectation will provide basic working mechanism and agreed internally for implementing the control function to the future.

\section{SEEKING IDEAL FORMAT OF SUPERVISORY CONCEPT} BY PARLIAMENT

Strong supervisory/control of Parliament against the government, sometimes considered as something that inhibits the effectiveness of the government in carrying out its functions at the level of executive. With the construction of the 1945 Constitution using presidential system of government, it is clear that the president cannot be imposed by Parliament ${ }^{13}$ and the position is very strong in national life. Although in other side, the

\footnotetext{
${ }^{12}$ Widodo, Joko., 2001. Good Governance telaah dari dimensi Akuntabilitas dan kontrol Birokrasi pada era desentralisasi dan otonomi daerah, Insan Cendekia, Surabaya, p. 39-40.

${ }^{13}$ Except for legal reasons, which is itself also difficult because it requires through the submission of proposals in order to obtain the opinion of the Constitutional Court (MK) and submitted by DPR to MPR about the possibility of holding the MPR session to discuss this proposal. Procedures for filing and political mechanisms in order to gain some sort of validity of the implementation of impeachment for the dismissal of the President and Vice President, to be read in Article 7 B of the 1945 Constitution. The difficulty in MPR, the requirement for a hearing and decision making are very heavy, which is through the MPR forum plenary meeting attended by at least $3 / 4$ of the total member
} 
president cannot dissolve parliament, as it is possible to do in a parliamentary system of government. With such construction, in fact concerns over collision of the President in exercise the government dan administrative are considered less reasoned. But on the other hand, the composition of diverse factions and political power of the President to differ with the majority chair holders in Parliament, the dependence of executive to Parliament can open opportunities to be realized.

Judged to have occurred distortion in the practice of constitutional that faced in everyday reality with the constitutional mandate that establishes a system of government adopted by the executive leadership in the President. Distortion has been invited a thinking to conduct re-ordering for supra-structure institutional and political infrastructure in order to create a government system that can function to their exercise duties and authorities effectively. The momentum of constitutional amendment about political parties, structure and position of MPR, DPR, DPD and DPRD, legislative election, president/vice-presiden election, and even legislation about the local government, it very showed the thinking.

In order to re-ordering such institutional, the political process to be encountered is not only related to the legislation function at the legislation level, but more than related to the rule under it. A rule that very determine the existence of Rule Procedure. This provision is not only contains session administrative procedure and its apparatus, but also contains substantial things in political. So that, the presence of rule procedure of Parliament is clearly has certain consequence to the relationship of legislative and other state institution, particularly about the relationship of Parliament with excutive party.

Particularly, the implementation of semi-presidential system can be very difficult, if the President and its supports has not majority vote in the body of legislative. An experience in France has been shown that the system can be function as a presidential system when the President and prime minister come from same party. Although, it will be a parliamentary system, if the President and prime minister dominate majority in legislative institution (without that the government is unable to survive): the role of president is very restricted especially for only international problems. A conflict between the president and parliament in Taiwan, in which for first the President is elected directly get parties that oppose its policies is able to dominate the majority in legislative institution, it is a strong examination or not under pressure. ${ }^{14}$

In the practice of administration, very thick occurs a combination in each government, which is between the presidential and parliamentary. Or, what is by Arend Lipjhart referred to as hybrid forms of government. ${ }^{15}$ In between each of elements combined in the government system, not least that gave birth to what is referred to as a semi-presidential system. The system gave birth to the various characteristics of the governments' efforts to survive in accordance with the principle of period for certain positions. Thus, Mathew Soberg Shugart and Scot Mainwaring ever mention that:

"Presidentialism can be defined in terms of two basic: characteristics: "separate origin (separate popular elections), and separate survival" (fixed terms of office both president and legislature). According to the second criterion, the proposal of the Committee on the Constitutional. System and the new Israeli system would clearly not qualify as presidential, but neither would be the French Fifth Republic: because the National Assembly can be dissolved prematurely. Moreover, a fixed term of office for the legislature can also be a characteristic of parliamentary system, as in the case of Norway."16

Governance system perspective adopted by each country is important to note in creating a consolidated political system construction democratically. Thus, the practice of government did not experience an ambiguous condition. If, for instance, adopted a presidential system, then the use of the rights of the Parliament in the level of control functions should also refer to the problem. Do not let the presidential system adopted constitutional claim, but instead in everyday practice what happens is the prevailing system of parliamentary government.This is clearly different, because each has its rationale and impact of its implementation at the level of practice that can be different from each other. For example, although the parliamentary system could result in the collapse of a government cabinet, when the parliamentary majority political forces impose no-confidence motion to the executive, but vice versa the executive also has a very strong authority. The authority that is when a chief executive, the Prime Minister may dissolve parliament and uses its authority to expedite the implementation of the elections in order to restore political support for himself. In contrast, in a presidential system, the position of the President that cannot be imposed by Parliament, except with impeachment reasons, but the executive does not have the authority to dissolve the parliament.

Daily administration political practice is closely related to building a party system that occurs, for each

and approved by at least $2 / 3$ of the members present, after the President and Vice President were given the opportunity to express explanation of the MPR Plenary Session. The legal reason is the opinion of the DPR that the President has violated the law in the form of treason, corruption, bribery, other felonies, or moral turpitude; and/or the opinion that the President and/or Vice President no longer qualifies as President and/or Vice President.

14 Ibid

15 Based on the result of research in 36 countries in various world parts, the conclusion is taken. See more Arend Lipjhart, Patterns of Democracy: Government Forms and Performance in Thirty Six Countries, Yale University Press, New Haven and London, 1999 , Page. 118

${ }_{16}$ Ibid., Page. 122 
option democracy can provide certain consequences. Arend Lipjhart based on the difference between the model of consensus democracy and majority, outlines the five differences related to what he called "the executive-parties dimension." "The first is the concentration of executive power in the hands of a single majority in the cabinet deal with widespread power sharing in a multi-party coalition. The second is the relationship of executive against legislature in which executives has dominant role dealing with the executive condition to the legislative with impartial powers. The third, the two-party system to deal with multi-party system. The fourth, the election system is majority and not balanced dealing with a proportional representation system. The fifth, various interest groups that compete fully and freely among them dealing with coordination and "corporatist" interest groups that aimed to compromise and concentration.

In addition to the characteristics of problem that distinguish systemically, between presidential and parliamentary with political practice every day, another important problem is the procedure of democracy itself. Political dynamics that occur disproportionately in the decision making in government level, especially with regard to parliamentary control to the executive, it is prone to the occurrence of a conflict between the political elite. That is, the conflict is not conducive to the process of democratic consolidation, because the difference of opinion is more meaningful as hostility rather than as an alternative opposition force. At this level is very determines the position of an agreement that can be reached by the political elite in the framework of the process of political institutionalization. ${ }^{18}$ One of the three categories of institutions that should be the focus is on representative institutions, namely the parliament, political parties, and elections. This is in order to assess whether political institutions are built capable of running consolidated democratic values, as well as control, open, participatory, and accountable.

Confidence in the option of negotiations between the political elite is often translated as something less positive. This is due to the political compromise that impressed not legal because it is outside the official institutional channels, when the parliament and the executive are facing a very sharp difference of opinion on a particular issue. In the period of leadership SBY and Megawati, the option to do a rainbow coalition with various political parties running in a very spacious room, this option is often translated as a pragmatism that is not consistent with forming a political system that is checks and balances. In fact, the critical attitude which increasingly flourished after industrial policy regime for a long period, in spite of the failure and success in achieving its economic growth targets, state institutions and political infrastructure is expected to contribute optimally and simultaneously efficient, so as not to get stuck in a situation setback or just being on the runway. The crisis of the capitalist industry in Southeast Asia (where Indonesia, the most severe) in 1997 and a growing middle class that is critical and the collapse of political system, upon entering a period of political freedom turned out to be still under tents seeking forms a relatively favorable institutional (institutionalized) with growing aspirations. ${ }^{19}$ Recording history of student occupation at DPR's building when demand Suharto to resign from power in 1998 really made an impression and give meaning to the rise of the role of Parliament in using the political rights during the period of long shackled by authoritarian regimes. ${ }^{20}$

If previously known various terms regarding extra-structure of certain political parties, as well as "half-room," "a quarter of a room," and so on, then in the era of reform through the party leaders and members in parliament. Any decision by parliament whether when experience constellation change or when the conducting of voting in faction composition, always deemed to have political consequences in power political. The leadership of government after the 1999 election and 2004, especially when Megawati and Susilo Bambang Yudhoyono comes, apparently learned of the fall of Abdurrahman Wahid, showing an accelerated pace of the use of means of political accommodation. Consequently, the cabinet becomes extremely great with the participation of leaders of cross-political parties. Consideration of current events on political phenomenon entered the era of direct election of the President by the people even in 2004, it reinforces the acceleration of election that way. In fact, when PDI Perjuangan began claiming to strive to be the political opposition, the move towards convergence of various forces in the camp of administration or specifically in these executives based on the political map of the parliament, to a certain extent on issues considered to be very strong with ownership interests of the party, in the reality is still going strong.

Strengthening the control function of Parliament becomes an urgent need to create legal certainty in State financial governance. The fact shows that the follow-up of Parliament to the result of BPK audit, particularly regarding the State loss often does not produce legal certainty. The findings are "hanging" without

\footnotetext{
17 See Chapter 1, mengenai "Introduction, Ibid., especially start in Page 3 and so forth.

${ }_{18}$ Two other categories, about State executive institution (Presidential institution, government system, bureaucracy, and military); on one hand, and judiciary institution and legal system accompany it. Read Larry Diamond, Developing Democracy toward Consolidation, IRE Press, Yogyakarta, 2003, Page. xxiii

19 Ariel Heryanto and Summit K Mandal, Menggugat Otorgerisme di Asia Tenggara, Kepustakaan Populer Gramedia (KPG), Jakarta, 2004, Page. 50-56

${ }^{20}$ About a wave of mass protest, includes students in various place is trying hard to force retreat Soeharto and New Order regime while its peak, Read Denny J.A, Democratization From Below: Protest Events and Regime Change in Indonesia 1997-1998, Pustaka Sinar Harapan, Jakarta, 2006, especially for understanding in Page. 27 
being able to be resolved legally. To be able to follow up the improvement of the fundamental weaknesses of State financial administration, BPK has been suggested to DPR and DPRD to establish a Panitia Akuntabilitas Publik (PAP). In parliamentary of foreign country the PAC is referred to as the Public Accountability Committee (PAC).

\section{CONCLUSION}

The essence of supervisory function of the Indonesian House of Representatives, philosophically based on manifestation of the principle of rule of law as well as sovereignty of the people as stipulated in the 1945 Constitution. The concept of representative institutions by DPR RI within the framework of the implementation of the sovereignty of the people and the State financial holder and also a means to fight for the aspirations of the people. The supervisory function of Parliament to executive including the management and responsibility of the State finances. Every government policy must get strict controls and is attached by DPR to ensure that government programs to benefit the people. The control function of Parliament plays an important role to realize good governance and clean governance. The control function of Parliament has been provided in the Constitution, in particular in Article 20A the 1945 Constitution.

The control function of DPR RI or Parliament today is not optimally run or as it should be, especially to follow up on the audit results of the management and responsibility of the State finance by BPK. It can be seen from the overview of audit result of BPK in throughout 2014-2016 and even in previous years related losses that have not been resolved. Strengthening of control of the Parliament should be parallel with the design of presidential system of government. In a sense, the multi-party today difficult for the control function due to more cross interest between the party groups (factions) in the Parliament. The Constitution has provided a number of rights to members of Parliament to support the control function, but the rights are less-utilized maximally because the interest of factions in the Parliament is more dominant than put statehood issues over the principles or people sovereignty or Indonesia people interests.

\section{REFERENCES}

[1] Arend Lipjhart, Patterns of Democracy: Government Forms and Performance in Thirty Six Countries, Yale University Press, New Haven and London, 1999, Page. 118

[2] Ariel Heryanto and Summit K Mandal, Menggugat Otorgerisme di Asia Tenggara, Kepustakaan Populer Gramedia (KPG), Jakarta, 2004, Page. 50-56

[3] Asmara, G. (2015). Penguatan Kelembagaan MPR dalam Sistem Ketatanegaran Negara Republik Indonesia. Hasanuddin Law Review, 1(3), 357-370. doi: http://dx.doi.org/10.20956/halrev.v1n3.115

[4] BPK Report: http://www.bpk.go.id/assets/files/ihps/2014/II/ihps_ii_2014_1428982182.pdf downloaded on Wednesday 1 February 2016 at 15.30.

[5] Denny J.A, Democratization From Below: Protest Events and Regime Change in Indonesia 1997-1998, Pustaka Sinar Harapan, Jakarta, 2006, Page. 27

[6] Deny Indrayana, Amandemen UUD 1945: Antara Mitos dan Pembongkaran, Bandung: Mizan, 2007, p. 276.

[7] Fitria. Penguatan fungsi DPR Melalui Perubahan Undang-undang No. 10 Tahnu 1954 tentang Hak Angket. Jurnal Cita Hukum, Vol. 1. No. 1. June 2014.

[8] Jimly Asshiddiqie. Format Kelembagaan Negara Dan Pergeseran Kekuasaan Dalam UUD 1945, Yogyakarta: FH UII Pers, 2002, p. 168.

[9] Larry Diamond, Developing Democracy toward Consolidation, IRE Press, Yogyakarta, 2003, Page. xxiii

[10] Moh. Mahfud, Perdebatan Hukum Tata Negara Pasca Amandemen Konstitusi, Jakarta: LP3ES, 2007, p. 66

[11] Peter Mahmud Marzuki., 2010. Penelitian Hukum. Jakarta: Kencana, p. 21

[12] Saldi Isra, Pergeseran Fungsi Legislasi, Jakarta: PT Raja Grafindo Persada, 2010, p. 156.

[13] TI Report on http://www.ti.or.id/index.php/publication/2016/01/27/corruption-perceptions-index-2015, Accessed on 27 January 2016

[14] Widodo, Joko., 2001. Good Governance telaah dari dimensi Akuntabilitas dan kontrol Birokrasi pada era desentralisasi dan otonomi daerah, Insan Cendekia, Surabaya, p. 39-40. 